\title{
SOCIOCULTURAL, SPIRITUAL, MORAL AND TUTOR SUPPORT FOR PEOPLE WITH DISABILITIES IN THE CONDITIONS OF HEIs (PROJECT)
}

Moskaliova Liudmyla, Doctor of Pedagogical Sciences, Professor at the Department of Social Work, Social Pedagogy and Preschool Education, Bohdan Khmelnytskyi Melitopol State Pedagogical University.

ORCID: 0000-0002-3428-8685

E-mail: moskalevalu1@gmail.com

Zhytnik Tetiana, PhD in Pedagogical Sciences, Senior Lecturer at the Department of Social Work, Social Pedagogy and Preschool Education, Bohdan Khmelnytskyi Melitopol State Pedagogical University.

ORCID: 0000-0003-2250-7251

E-mail: zhytnik_tetiana@mdpu.org.ua

Podpliota Svitlana, Graduate Student at the Department of Social Work, Social Pedagogy and Preschool Education, Bohdan Khmelnytskyi Melitopol State Pedagogical University.

ORCID: 0000-0002-5184-9907

E-mail: spodpleta@gmail.com

Topicality of the research is considered through the lens of evolution in education and people with disabilities in the conditions of a new model of inclusive environment. The purpose of the article is to demonstrate the technology of the development of cultural and social activity of people with disabilities in the conditions of higher education institutions in the process of project activity. Sociocultural, moral, spiritual and tutor support, based on gained experience, should provide students of higher education institutions with the help of self-selection of sociocultural and personal position, the opportunity to confidently express their opinion, to be active, to have their own social position, taking into account moral principles and spiritual inner fullness.

Keywords: inclusion, people with special educational needs, institution of higher education, sociocultural development, spiritual and moral development, tutoring, tutor's support, project activity.

\section{СОЦАЛЬНО-КУЛЬТУРНИЙ, ДУХОВНО-МОРАЛЬНИЙ ТА ТЬЮТОРСЬКИЙ СУПРОВІД ОСОБИСТОСТІ З ІНВАЛІДНІСТЮ В УМОВАХ ЗАКЛАДІВ ВИЩОЇ ОСВІТИ (ПРОЕКТ)}

Москальова Людмила, доктор педагогічних наук, професор кафедри соціальної роботи, соціальної педагогіки та дошкільної освіти, Мелітопольський державний педагогічний університет імені Богдана Хмельницького.

ORCID: 0000-0002-3428-8685

E-mail: moskalevalu1@gmail.com 
Житнік Тетяна, кандидат педагогічних наук, старший викладач кафедри соціальної роботи, соціальної педагогіки та дошкільної освіти, Мелітопольський державний педагогічний університет імені Богдана Хмельницького.

ORCID: 0000-0003-2250-7251

E-mail: zhytnik_tetiana@mdpu.org.ua

Подпльота Світлана, аспірант кафедри соціальної роботи, соціальної педагогіки та дошкільної освіти, Мелітопольський державний педагогічний університет імені Богдана Хмельницького.

ORCID: 0000-0002-5184-9907

E-mail: spodpleta@gmail.com

\begin{abstract}
Актуальність дослідження розглядається у площині еволюиії у сфері освіти та особистості з інвалідністю в умовах нової моделі інклюзивного простору. Україна, ратифікувавши Лісабонську конвениію та приєднавшись до Болонської деклараџії, також повинна виконувати всі взяті на себе зобов'язання. Це передусім стосується стратегічного пріоритету забезпечення рівності та соціальної взасмодії в рамках Європейської співпрачі в освіті. Власне Україна, як учасничя Болонського прочесу, повинна використовувати роль освіт як ключовий інструмент досягнення успішного соціального захисту та розвитку моделі соиіальної інклюзії осіб із особливими потребами/інвалідністю. Сочіально-культурний, тьюторський та духовно-моральний супровід на основі отриманого досвіду, має надати студентам закладів вищої освіти допомогу на шляху самостійного вибору соціально-культурної та особистісної позицї̈, можливість впевнено висловлювати свою думку, бути активним, мати власну громадську позицію, враховуючи моральні принципи та духовну внутрішню наповненість. Стаття має на меті продемонструвати проєкт та описати його технологію в процесі реалізації проєктної діяльності, розробленої з урахуванням відсутності узгодження сочіальних механізмів та умов культурної активності особистості з обмеженими можливостями та орієнтований на розвиток творчих, культурно-дозвіллєвих та сочіальних потреб студентів з інвалідністю 6 умовах закладів вищої освіти. Соціально-культурний та духовно-моральний супровід розглядається як створення у закладах вищої освіти умов для ефективної, спрямованої та активної самореалізації студентів у навчально-виховному процесі, а, надалі, використання отриманих навичок та позитивного досвіду в соиіальній, особистісній та міжособистісній сфері, трудовій та культурній діяльності з урахуванням їхніх психофізичних можливостей, інтересів, принцииів та уподобань. Підкреслюється важливість включення тьютора в освітній прочес студента, який має мобілізувати внутрішні резерви вихования для того, щоб у подальшому той сам міг впоратися зі своӥми труднощами.
\end{abstract}

Ключові слова: інклюзія, особистість з особливими освітніми потребами, заклад вищої освіти, сочіально-культурний розвиток, духовно-моральний розвиток, тьютор, тьюторський супровід, проєктна діяльність.

For more than half a century, the problem of people with disabilities is a subject of the United Nations and other international organizations' great attention. Many documents are aimed at providing equal rights for people with disabilities with all members of society, in particular, for high-quality education. These documents were adopted by the European community. According to the Communiqué of the Conference of European Ministers Responsible for Higher Education (Leuven and Louvain-la-Neuve, 28-29 April 2009), the Bologna Process countries undertook to create all training facilities for people with disabilities.

Having ratified the Lisbon Convention and joined the Bologna Declaration, Ukraine must also comply with all its obligations. This primarily concerns the strategic priority of ensuring equality and social interaction within the framework of European cooperation in 
education. Actually, Ukraine being a participant of the Bologna process should use the role of higher education as a key instrument for achieving successful social protection and developing a model of social inclusion of people with disabilities.

Research aim: to demonstrate the project and its technology in the implementation activity process, taking into account the lack of harmonization of social mechanisms and conditions of people with disabilities cultural activity focused on the development of creative, cultural and social needs of students with disabilities in conditions of higher education institutions.

Research subject: students with special educational needs who study in institutions of higher education.

Many native and foreign researches wrote about this problem. Among them: V. Allen [1], N. Almog [2], P. Ashwin [3], R. Aust [4], I. Bekh [5], D. Bell \& E. Swarts [6], S. Davies [7], F. Forster, D. Hounsell \& S. Thompson [8], J. Harvey [9], D. Goodley, B. Hughes \& L. Davis [10], P. Harpur [11], P. Kermit \& S. Holiman [12], A. Kruse \& S. Oswal [13], L. Fox [14], D. Mitchell [15], H. Mayr-Harting [16], B. Ostiguy [17], D. Palfreyman \& T. Tapper [18], D. Rayan [19], D. Rheinheimer [20], M. Weimer [21], S. Zaussinger \& B. Terzieva [22].

The main goal of the modern society is respect for human diversity, the establishment of principles of tolerance and solidarity, which provides protection, integration and active participation in the society of all segments of the population, including people with disabilities. The principle of the availability and observance of human rights regarding equal access to quality education is the basis for integration. The European community has argued that education should be provided without any discrimination against people with disabilities. Thus, disability is not an obstacle. Moreover, there is the ideology in the basis of inclusive education that excludes any discrimination of the individual, ensures equal treatment of all people and creates special conditions for the sociocultural formation of the individual in all educational institutions.

The statement of the problem situation and the relevance of the problem determines the research hypothesis. It is believed that sociocultural, moral, spiritual and tutor support, based on gained experience, provide students of higher education institutions with the help of self-selection of sociocultural and personal position, the opportunity to express their opinion confidently, to be active, to have their own social position, taking into account moral principles and spiritual inner fullness.

In our research sociocultural, spiritual, moral and tutor support is considered as the creation of conditions in the institutions of higher education for the effective, directed and active self-realization of students in the educational process. Then for the use of acquired skills and positive experience in social, personal and interpersonal spheres, labor and cultural activity, taking into account their psychophysical possibilities, interests, principles and preferences. include:

The general principles of sociocultural, moral, spiritual and tutor support for students

1. The principle of pedagogization aimed at "learn to study".

2. The principle of student-centred approach that recognize a student's personality as the highest social and cultural value; respect for the specialness and cultural identity of each individual, recognition of the rights and freedom of people in the socio-cultural sphere (selfdevelopment, self-affirmation and self-realization of man). 
3. The principle of focusing on cultural and value relationships and the organization of culture and creativity in groups and communities is permeated with a humanistic approach to building interpersonal relationships in the process of leisure and creativity.

4. The principle of solidarity and continuity of cultural-historical, social-pedagogical and national-ethnic experience, traditions and innovations (formation of moral and aesthetic norms of behaviour).

5. The principle of national, ethnic and spiritual ceremonies involves the use of national traditions, features of folk art, folklore, national crafts, etc.

6. The principle of regional policy in the socio-cultural sphere (decentralization).

We emphasize the importance of incorporating the tutor into the educational process, who must mobilize the students' internal reserves in order to teach them to cope with difficulties in future. At the same time, the educator has to develop the opportunity to evaluate the causes of difficulties correctly and motivate to find ways of solving problems independently by strengthening the faith of the students in themselves.

Sample / Participants / Group

Here is an example of the implementation of the project of sociocultural, tutor, spiritual and moral support in Bohdan Khmelnytskyi Melitopol State Pedagogical University (Melitopol, Zaporizhzhia Region, Ukraine).

Experimental work was carried out in 2017-2018. The total number of recipients involved in the work was 36 students aged 18 to 23 . At the stage of experimental work, a group of students from Bohdan Khmelnytskyi Melitopol State Pedagogical University was identified for the implementation of the project and the analysis of the result.

The purpose of the project is direct and active inclusion and functioning of students with disabilities in a specific social environment (the institution of higher education), the formation of their sociocultural status, moral and spiritual choices, conducting their participation in social and cultural processes of the higher education institutions.

The main aim and priority of the event is the creation of a centre, the directions of which are sociocultural, spiritual, moral and tutor support of students with disabilities in the higher education institutions.

The main task of the centre is to form a highly educated, competitive, spiritually active graduate of the higher education institutions, taking into account the individual physical level and psychological support.

The aim of the centre is to create conditions for education and socialization of students with disabilities in the higher education institution, access to education, social protection and professionalism in future profession.

Sociocultural, spiritual, moral and tutor support of people with disabilities is a subject of cultural national heritage and bearers of cultural traditions. Tutoring in the institution of higher education is an opportunity to support and develop an initiative author's attitude in students with disabilities towards their own educational activities.

Designing the image of future, we see within the framework of cooperation with:

- The Centre of Spiritual and Moral Development of Bohdan Khmelnytskyi Melitopol State Pedagogical University;

- Melitopol Children's Art School;

- Melitopol High School of Culture;

- Melitopol Children's Hospital ("Friendly Clinic to Youth"); 
- Charitable Organizations "Everything is Possible", "We are Women";

- "Dreams Come True";

- Melitopol Museum of Local Lore;

- Memorial of Culture ("Stone Grave").

The creation of a special author's program of spiritual, moral, sociocultural, tutor support for students with disabilities in the conditions of higher education institutions is an additional advantage for the European level of development.

Development correctional programs of spiritual, moral and sociocultural abilities of people with disabilities: music therapy, participation in performances, library-therapy, cryotherapy, an expansion of social space, the ability to stand up and be counted, to communicate with others, to select groups of interests.

The stages of the project program implementation:

Stage 1. Planning and Abilitation:

1. Structural and content analysis of the model of support for students with disabilities: the determination of goals, objectives, directions, stages, subject, means, forms, methods and technologies for the implementation of support.

2. Selection of diagnostic methods, methods for monitoring the effectiveness of the support.

3. Development of the structure and content of individual, group and independent work (consultations, reflexive sessions).

4. Development of the work system (trainings, round tables) for the formation of confident behaviour, the development of leadership qualities, the ability to make a responsible choice.

Stage 2. Practice and Abilitation:

1. Conducting: group consultations, individual consultations for revealing individual educational requests of students with disabilities, taking into account the content of individual, group, independent work.

2. Practical evaluation of personal development trainings "Confident Behaviour Training", "Adaptation of a first year student".

3. Practical evaluation of educational events: educational cartography, forum of success, competitions, festivals, presentations.

4. Development of recommendations for teachers, students on the organization of educational system and an expansion of social space of students with disabilities.

Stage 3. Achievement Control:

1. Educational program results analysis of the support for students with disabilities.

2. Formulating main conclusions and recommendations for constructing a model of support for students with disabilities.

3. Publishing the results of the project.

4. Conducting an examination of the results and products of innovative activity.

5. Estimation of the effectiveness of the model of supporting the individual educational program of students with disabilities (analysis of students' trajectories of life).

Means of control and ensuring the reliability of the results of the research are also planned, such as:

- implementation of an individual educational program by each student with a 
disability;

- development of personal potential: cognitive and professional interests, abilities, opportunities, competencies;

- self-determination in the choice of future professional activity;

- educational activity of students with disabilities;

- the ability to analyse, reflect, and adjust their own activities;

- the ability to independently formulate and implement life and professional tasks.

Methods for tracking the results of the research:

- educational monitoring;

- observation;

- methods of statistics;

- methods of psychology (sociometry, individual cards, testing);

- questionnaires;

- reflexive sessions;

- educational cartography;

- $\quad$ portfolio of students with disabilities;

- data analysis on the implementation of individual educational requests of students with disabilities;

- $\quad$ analysis of exam results, attestation;

- data analysis on the personal and socially significant achievements of students with disabilities;

- data analysis on students' trajectories of life.

The expected result is the reformation of the content of work with disabled students by implementation of spiritual, moral, sociocultural and tutor support. Based on the implementation of the program, the level and quality of socialization of students with disabilities will increase, which will enable them to design their future and form the necessary resources for life plans.

During the implementation of spiritual, moral, sociocultural and tutor support, such events were organized and conducted:

- All-Ukrainian Scientific and Practical Conference on Aesthetic Education (one of the proposed directions of work - Inclusion);

- The Scientific and Practical Conference "Construction of Inclusive Environment in the System of Education: Theory and Practice";

- Regional cultural and educational event "Spiritual Spring - 2018";

- Training for educators of inclusive classes "Charming Orange Room" (in Melitopol Museum of Local Lore);

- First Academy of Contemporary Children's Art “Art Lab” (Melitopol Children's Art School) for children with musculoskeletal disorders.

The project involves a combination of complementary organizations of the required profile with qualification and competence for the successful implementation of all aspects of the project, namely, from education sector, science, youth and sports, culture, charitable and public spheres.

To implement the proposed project, partners were chosen in accordance with the kinds of support. 
Spiritual and Moral Support:

- Cooperation with the Laboratory of Spiritual and Moral Education of the Scientific Research Institute of Spiritual Development of Man of Volodymyr Dahl East Ukrainian National University;

- Melitopol Museum of Local Lore;

- Memorial of Culture "Stone Grave".

Sociocultural support:

- Melitopol Children's Art School;

- Melitopol High School of Culture;

- Melitopol Children's Hospital ("Friendly Clinic to Youth");

- Charitable Organizations "Everything is Possible";

- Charitable Organizations "We are Women";

- Melitopol Museum of Local Lore.

Tutor support:

- $\quad$ Tutor Centre of Excellence in Bohdan Khmelnytskyi Melitopol State Pedagogical University.

Different trainings (for improving adaptation, self-confidence, ability to conduct dialogue, professional growth and ability to overcome difficulties), university events, seminars, round tables, conferences on issues of health promotion were conducted.

Trainings were organized and conducted with disabled students in the following directions: effective interpersonal communication skills of students, self-control training; selfcontrol development with skills of counteraction of pressure of environment; training effective forms of behaviour in stressful situations; formation of leadership potential; increasing self-esteem of people with disabilities; group psychotherapy for people with disabilities, etc.

Project realization enables:

- $\quad$ to organize a Centre of Tutor Support for Students with Disabilities in Bohdan Khmelnytskyi Melitopol State Pedagogical University;

- to support and strengthen the students' self-confidence and interest of the state and non-state services of the region to their problems;

- to provide practical assistance for students with disabilities in education;

- to recognize practical steps in solving educational problems of students with disabilities in tutor's activity;

- to change the passive position of many professionals, heads of institutions and companies into interested and active for helping students with disabilities;

Thus, it is possible to identify the stages of sociocultural, moral, spiritual and tutor support:

1. Research analysis and determination:

- general readiness of first-year student for social and cultural activities in institutions of higher education, their creative possibilities; moral and spiritual principles and attitudes;

- identifying adaptive problems of students may affect their sociocultural life in the institution of higher education and the formation of moral and spiritual principles with the help of psychological and pedagogical methods of diagnostics (questionnaires, tests, methods of psychological research);

- classification of the identified problems; 
- classification of needs and expectations from the sociocultural sphere and moral upbringing during the study of first-year students at the institutions of higher education.

2. Aim setting and plan formation of sociocultural, moral, spiritual support in accordance with the solution of the tasks of adaptation and the results obtained.

3. Direct implementation of sociocultural, moral and spiritual support.

4. Monitoring and results analysis, correlation with the tasks.

5. Correction of the plan of sociocultural, moral and spiritual support, based on the analysis of the results.

Therefore, nowadays one of the priority tasks of a democratic society is finding tools for spiritual, moral and sociocultural support for students with disabilities, who study at institutions of higher education, with the inclusion of tutor support. During pilot experimental work (2017-2018 years) 36 students with disabilities of Bohdan Khmelnytskyi Melitopol State Pedagogical University participated in the study of the project implementation quality (Table 1).

The quality and feasibility of the proposed project activity was based on the following indicators (Table 1):

- volunteer work of students with disabilities, aimed at improving relations in society and the ability to give reasons for their own views;

- involve students with disabilities in educational work in city, district, region.

Table 1

\begin{tabular}{|c|c|c|c|c|c|c|c|c|c|}
\hline \multirow{3}{*}{ № } & \multirow{3}{*}{ Criterion } & \multicolumn{8}{|c|}{ Levels } \\
\hline & & \multicolumn{2}{|c|}{ High } & \multicolumn{2}{|c|}{ Sufficient } & \multicolumn{2}{|c|}{ Moderate } & \multicolumn{2}{|c|}{ Low } \\
\hline & & CG & EG & CG & EG & CG & EG & CG & EG \\
\hline 1 & $\begin{array}{l}\text { Volunteer work of } \\
\text { students with disabilities, } \\
\text { aimed at improving } \\
\text { relations in society }\end{array}$ & 16,7 & 18,5 & 26,8 & 28,5 & 29,3 & 28,6 & 27,5 & 25,4 \\
\hline 2 & $\begin{array}{l}\text { Participation of students } \\
\text { with disabilities in } \\
\text { educational work in city, } \\
\text { district, region }\end{array}$ & 13,5 & 16,4 & 27,1 & 34,9 & 20,4 & 15,4 & 38 & 33,3 \\
\hline
\end{tabular}

After project realization, we can identify the following directions for sociocultural, moral, spiritual and tutor support for students with disabilities in the process of adaptation to the social environment in institutions of higher education:

1) individual work with ordinary students on their inclusion in the sociocultural life of the institution of higher education (city, region, country), with a view to develop the moral and spiritual component;

2) individual social and cultural work with disabled students in order to develop the spiritual component and formulate moral principles;

3) organization of joint activities for ordinary students and students with disabilities to include in the sociocultural life of the institution of higher education, in order to develop their moral and spiritual values.

1. Sociocultural, moral, spiritual and tutor support, based on gained experience, 
should provide students of institutions of higher education with the help of self-selection of sociocultural and personal position, the opportunity to express their opinion confidently, to be active, to have their own social position, taking into account moral principles and spiritual inner fullness.

2. Individual sociocultural work with ordinary students provides:

- formation of the basic components of the student-centred approach (each person is unique),

- tolerant attitude to "not like all the others", stimulating and supporting the desire of complicity in students with disabilities during sociocultural, extracurricular and leisure activities, etc.;

- formation of a facility for joint productive, active and purposeful sociocultural activity of students with disabilities.

3. Organization of joint activities for ordinary students and students with disabilities for including in the sociocultural life of the institution of higher education involves:

- creating a favourable climate for adaptation of the groups in the institution for the purpose of joint sociocultural activities;

- formation of a student's staff (ordinary students and students with disabilities) in order to implement social and cultural activities;

- conducting trainings (adaptive, educational), role-playing games, by which students learn to communicate, consistently express and defend their own position, deconfliction;

- involvement of students in creation of clubs, organizations, etc.;

- attraction of a first year student to the system of student self-government, which is a form of student's democracy with the corresponding rights, opportunities and responsibilities;

- inclusion of students in sociocultural spheres of the institution's (city's) life.

It is planned to organize project activities with teachers and social, cultural, structural divisions, namely:

4. Organization of project activity with educators:

- training the student-centred learning approaches; development and introduction of courses (online courses, volunteering, etc.);

- realization of activities aimed at establishing relations between the social and cultural environment;

- distribution of information about the project (about achievements, results, etc.).

5. Cooperation with social structural divisions:

- charitable organizations, charitable foundations and public organizations (joint training "Being a volunteer", "Peer-to-peer"), joint actions, flash mobs, etc.;

- creation of own social organization (project activity), creation of own site;

- collaboration with the centres of the Supporting Young People in Difficult Straits, Friendly Clinic to Youth (conducting trainings and roundtables about healthy lifestyle, sexual education: "Young mothers", "Happy Family", etc.), cooperation with mass media (publications).

6. Cooperation with cultural subdivisions:

- creative unions,

- clubs, 
- extra-university establishments,

- libraries,

- museums.

Possible events:

- creation of the theatre "Alone";

- organization of the creative fine arts studios (studio of painting, graphic arts, decorative and applied arts);

- organization of photo and ethno-arts studios.

\section{REFERENCES}

1. Allen, V. I. (1976). Children as Teachers. Open University Press, 178, 135.

2. Almog, N. (2018). "Everyone is normal, and everyone has a disability": Narratives of university students with visual impairment. Social Inclusion, 6(4), 218-229. DOI: http://dx.doi.org/10.17645/si.v6i4.169

3. Ashwin, P. (2005). Variation in students' experiences of the 'Oxford Tutorial. Higher Education.

4. Aust, R. (2018). Disability in higher education: Explanations and legitimisation from teachers at Leipzig University. Social Inclusion, 6(4), 125-136. DOI: http://dx.doi.org/10.17645/si.v6i4.1641

5. Bekh I., D. (2015). Vybrani naukovi pratsi. Vykhovannia osobystosti. Vol. 1 [Selected scientific works. Parenting. Vol. 1]. Chernivtsi: Bukrek, 13 [in Ukrainian].

6. Bell, D. \& Swart, E. (2018). Learning experiences of students who are hard of hearing in higher education: Case study of a South African university. Social Inclusion, 6(4), 137-148. DOI: http://dx.doi.org/ 10.17645/si.v6i4.1643

7. Davies, S. (2004). School Choice by Default? Understanding the Growing Demand for Private Tutoring in Canada. American Journal of Education, 110(3). DOI: https://doi.org/10.1086/383073

8. Forster, F., Hounsell, D. \& Thompson, S. (1995). Tutoring and Demonstrating: A Handbook. Centre for Teaching, Learning and Assessment, University of Edinburgh.

9. Harvey, J. (2018). Contemporary social theory as a tool to understand the experiences of disabled students in higher education. Social Inclusion, 6(4), 107-115. DOI: http://dx.doi.org/10.17645/si.v6i4.1602

10. Goodley, D., Hughes, B., \& Davis, L. (2012). Disability and social theory: New developments and directions. London: Palgrave.

11. Harpur, P. (2012). From disability to ability: Changing the phrasing of the debate. Disability \& Society, 27(3), 325-337. https://doi.org/10.1080/09687599.2012.654985

12. Kermit, P. \& Holiman, S. (2018). Inclusion in Norwegian higher education: Deaf students' experiences with lecturers. Social Inclusion, 6(4), 158-167. DOI: http://dx.doi.org/10.17645/si.v6i4.1656

13. Kruse, A. K. \& Oswal, S. K. (2018). Barriers to higher education for students with bipolar disorder: A critical social model perspective. Social Inclusion, 6(4), 194-206. DOI: http://dx.doi.org/10.17645/ si.v6i4.1682

14. Lane Fox, R. (2001). Tutorials in Greats and History: The Socratic Method. In D. Palfreyman (Ed.). The Oxford Tutorial. Oxford: Blackwell's.

15. Mitchell, D. T. (2017). Disability, diversity, and diversion: Normalization and avoidance in higher education. Disability, avoidance and the academy, London: Routledge, 9-21.

16. Mayr-Harting, H. (2006). The Oxford Tutorial. Convocation Curriculum delivered November. Lawrence University, Appleton, Wisconsin.

17. Ostiguy, B. J. (2018). The inherent value of disability in higher education. Social Inclusion, 6(4), 241-243. DOI: http://dx.doi.org/10.17645/si.v6i4.1737

18. Palfreyman, D. \& Tapper, T. (2000). Oxford and the Decline of the Collegiate Tradition. Woburn Press, London, Portland.

19. Rayan, D. (2001). Perfection in politics and philosophy. In D. Palfreyman (Ed). The Oxford Tutorial, Oxford: Blackwell's, 78-86.

20. Rheinheimer David, C. (2010). Tutoring: A Support Strategy for At-Risk Students, TLAR, 15(1), 23-34.

21. Weimer, M. (2002). Learner centered teaching: five key changes to practice. John Wiley and Sons, Inc., USA, 288.

22. Zaussinger, S. \& Terzieva, B. (2018). Fear of stigmatisation among students with disabilities in Austria. Social Inclusion, 6(4), 182-193. DOI: http://dx.doi.org/10.17645/si.v6i4.1667 